\title{
Predicting corn digestible and metabolizable energy content from its chemical composition in growing pigs
}

Quanfeng Li, Jianjun Zang, Dewen Liu, Xiangshu Piao, Changhua Lai and Defa Li*

\begin{abstract}
Background: The nutrient composition of corn is variable. To prevent unforeseen reductions in growth performance, grading and analytical methods are used to minimize nutrient variability between calculated and analyzed values. This experiment was carried out to define the sources of variation in the energy content of corn and to develop a practical method to accurately estimate the digestible energy (DE) and metabolisable energy (ME) content of individual corn samples for growing pigs. Twenty samples were taken from each of five provinces in China (Jilin, Hebei, Shandong, Liaoning, and Henan) to obtain a range of quality.

Results: The DE and ME contents of the 100 corn samples were measured in $35.3 \pm 1.92 \mathrm{~kg}$ growing pigs (six pigs per corn sample). Sixty corn samples were used to build the prediction model; the remaining forty samples were used to test the suitability of these models. The chemical composition of each corn sample was determined, and the results were used to establish prediction equations for DE or ME content from chemical characteristics. The mean DE and ME content of the 100 samples were 4,053 and 3,923 kcal/kg (dry matter basis), respectively. The physical characteristics were determined, as well, and the results indicated that the bulk weight and 1,000-kernel weight were not associated with energy content. The DE and ME values could be accurately predicted from chemical characteristics. The best fit equations were as follows: $\mathrm{DE}$, $\mathrm{kcal} / \mathrm{kg}$ of $\mathrm{DM}=1062.68+(49.72 \times \mathrm{EE})+(0.54 \times$ $\mathrm{GE})+(9.11 \times$ starch$)$, with $\mathrm{R}^{2}=0.62$, residual standard deviation $(\mathrm{RSD})=48 \mathrm{kcal} / \mathrm{kg}$, and $P<0.01 ; \mathrm{ME}, \mathrm{kcal} / \mathrm{kg}$ of dry matter basis $(D M)=671.54+(0.89 \times D E)-(5.57 \times N D F)-(191.39 \times$ ash $)$, with $R^{2}=0.87, R S D=18 \mathrm{kcal} / \mathrm{kg}$, and $P<0.01$.

Conclusion: This experiment confirms the large variation in the energy content of corn, describes the factors that influence this variation, and presents equations based on chemical measurements that may be used to predict the DE and ME content of individual corn samples.
\end{abstract}

Keywords: Corn, Digestible energy, Metabolizable energy, Pigs, Prediction equation

\section{Background}

Corn is the principal cereal grain used in swine diets because it is widely grown, have highly DE and ME, and is generally economical. However, variation in nutrient content of corn has the potential to greatly affect profits in pig production. For example, variation in valuable energy may translate to economically significant changes in feed conversion [1]. To prevent unforeseen reductions in growth performance, grading and analytical methods are

\footnotetext{
* Correspondence: Defali@public2.bta.net.cn

State Key Laboratory of Animal Nutrition, Ministry of Agriculture Feed Industry Centre, China Agricultural University, Beijing 100193, China
}

used to minimize nutrient variability between calculated and analyzed values. In the present Chinese grading system, corn is graded based on bulk weight and damaged kernels even though other factors may affect its feeding value.

Nutrient digestibility of corn is affected by agronomic conditions, genetics, postharvest processing, storage conditions, and anti-nutritional factors [2,3]. Differences between corn samples can yield variability in available energy, nutrient digestibility and growth performance in pigs [4-6]. However, the United States department of agriculture (USDA) corn grading system and Chinese grading system are based primarily on physical characteristics, such as bulk weight. Therefore, corn is priced with 
disregard to variations in chemical quality due to the vast scale of analysis that would be required commercially [6] and the acceptance that nutrient value of feed ingredients may be constant based on broad-based quality designations [7].

By potentially ignoring inherent variation in nutrient content and digestibility, the grading methods used to evaluate corn, such as bulk weight, may be poor estimators of feeding value $[8,9]$. Furthermore, prediction equations for digestible energy (DE) and metabolisable energy (ME) in feed ingredients based on chemical composition can be a useful tool in feed ingredient evaluation, but such equations are currently available only for barley [3], DDGS [10,11], wheat [12], and complete diets [13]. To our knowledge, there is a lack of peer-reviewed information regarding the combination of these techniques to predict nutrient digestibility of diverse samples of corn in pigs. The objectives of the present study were to characterize the nature of the variation in the energy content of corn and to develop a system(s) that accurately estimates the $\mathrm{DE}$ and ME levels in individual corn samples.

\section{Methods}

\section{Selection and preparation of the corn samples}

The corn samples were obtained from the main corn producing areas of China. Jilin, Liaoning, and northern Hebei provinces are spring corn-growing areas; seeds are planted from the end of April to May. Southern Hebei, Shandong and Henan provinces are summer corngrowing areas; seeds are planted in mid-June. To obtain a range of quality of Chinese feed corn, a total of 100 corn samples were taken, twenty from each of five provinces (Jilin, Hebei, Shandong, Liaoning, and Henan). From each location, one sample was selected to be below average and another was selected to be above average in bulk weight. Thus, the primary goal of the sample selection process was not to compare cultivars, but rather to provide a diverse array of corn samples for investigation into the nature of energy variability in corn. The chemical characteristics and physical characteristics of corn are shown in Table 1. The Institutional Animal Care and Use Committee at China Agricultural University (Beijing, China) reviewed and approved the protocols used in this study.

\section{Experimental design}

Sixty corn samples were randomly selected from the five provinces of China, every province contains twelve samples, to develop a prediction model for DE and ME that could be utilized for the formulation of diets for pigs. The remaining forty corn samples were used to test the accuracy of the DE prediction model. One hundred diets were formulated to contain $96.8 \%$ of one of each of the corn samples and 3.2\% minerals and vitamins (Table 2). Corn was assumed to be the only source of energy in the diet as the slight contribution of energy from vitamin and mineral premixes was assumed to be negligible. Vitamins and minerals were supplied at levels formulated to exceed the requirements of 20 to $50 \mathrm{~kg}$ growing pigs as defined by NRC [14].

The total experiment consisted of five digestibility trials conducted from October 2011 to March 2012 under similar experimental conditions. We have ten metabolism rooms, and each room has twelve metabolism cages. Six workers were employed to collect feces. Each successive trial measured twenty diets. A total of six hundred crossbred barrows (Duroc $\times$ Landrace $\times$ Yorkshire) (initial BW, $35.3 \pm 1.9 \mathrm{~kg}$ ) were used according to a completely randomized design, and each diet was tested with six pigs.

Table 1 Chemical and physical characteristic characteristics of 100 corn samples

\begin{tabular}{|c|c|c|c|c|c|}
\hline Item & Mean & $\mathrm{SD}^{*}$ & $\mathrm{CV}^{*}$ & Minimum & Maximum \\
\hline \multicolumn{6}{|c|}{ Chemical composition, \% of DM } \\
\hline Crude protein & 9.69 & 0.50 & 5.16 & 7.78 & 11.03 \\
\hline Ash & 1.36 & 0.14 & 10.07 & 0.99 & 1.79 \\
\hline Calcium & 0.03 & 0.01 & 26.67 & 0.01 & 0.03 \\
\hline Phosphorus & 0.25 & 0.03 & 11.20 & 0.18 & 0.32 \\
\hline NDF & 11.13 & 0.93 & 8.35 & 9.56 & 17.36 \\
\hline ADF & 2.29 & 0.23 & 10.04 & 1.86 & 2.95 \\
\hline Ether extract & 3.65 & 0.54 & 14.79 & 2.04 & 4.81 \\
\hline Starch & 72.77 & 3.32 & 4.56 & 53.46 & 79.80 \\
\hline Gross energy, kcal/kg of DM & 4,447 & 44.96 & 1.01 & 4,357 & 4,537 \\
\hline \multicolumn{6}{|l|}{ Physical characteristic } \\
\hline Bulk weight, g/L & 698.68 & 25.91 & 3.71 & 573.62 & 752.35 \\
\hline 1,000 kernel weight, $\mathrm{g}$ & 325.48 & 41.16 & 12.64 & 220.20 & 411.10 \\
\hline
\end{tabular}

"SD, Standard deviation; ${ }^{*} \mathrm{CV}$, Coefficient of variation. 
Table 2 Composition of the experimental diets (as-fed basis) fed to growing pigs for comparison of the energy digestibility between different corn samples

\begin{tabular}{lc}
\hline Ingredient & $\%$ \\
\hline Corn & 96.8 \\
Antioxidant $^{1}$ & 0.1 \\
Dicalcium phosphate & 1.7 \\
Limestone & 0.6 \\
Salt & 0.3 \\
Vitamin and trace mineral premix $^{2}$ & 0.5 \\
\hline
\end{tabular}

${ }^{1}$ Santoquin MAX composite antioxidant, contained no less than $10 \%$ Ethoxyquin, no less than 3\% Butylated Hydroxytoluene (BHT) and Citric acid, provided by Novus International, Inc.

${ }^{2}$ Premix provided the following per $\mathrm{kg}$ of complete diet for growing pigs: vitamin $A, 5,512 \mathrm{IU}$; vitamin $\mathrm{D}_{3}, 2,200 \mathrm{IU}$; vitamin $\mathrm{E}, 30 \mathrm{IU}$; vitamin $\mathrm{K}_{3}, 2.2 \mathrm{mg}$; vitamin $B_{12}, 27.6 \mu \mathrm{g}$; riboflavin, $4 \mathrm{mg}$; pantothenic acid, $14 \mathrm{mg}$; niacin, $30 \mathrm{mg}$; choline chloride, $400 \mathrm{mg}$; folacin, $0.7 \mathrm{mg}$; thiamine $1.5 \mathrm{mg}$; pyridoxine $3 \mathrm{mg}$; biotin, $44 \mu \mathrm{g}$; $\mathrm{Mn}, 40 \mathrm{mg}(\mathrm{MnO}) ; \mathrm{Fe}, 75 \mathrm{mg}\left(\mathrm{FeSO}_{4} \cdot \mathrm{H}_{2} \mathrm{O}\right) ; \mathrm{Zn}, 75 \mathrm{mg}(\mathrm{ZnO})$; $\mathrm{Cu}, 100 \mathrm{mg}\left(\mathrm{CuSO}_{4} \cdot 5 \mathrm{H}_{2} \mathrm{O}\right) ; \mathrm{l}, 0.3 \mathrm{mg}(\mathrm{Kl}) ; \mathrm{Se}, 0.3 \mathrm{mg}\left(\mathrm{Na}_{2} \mathrm{SeO}_{3}\right)$.

Pigs were individually housed in stainless steel metabolism cages $(1.4 \mathrm{~m} \times 0.45 \mathrm{~m} \times 0.6 \mathrm{~m})$, and were weighed at the beginning of each period. Pigs were adapted to the diet and the digestibility cage for more than ten days before total collection of feces and urine for five days. The crates were located in an environmentally controlled room with a temperature of $22 \pm 1^{\circ} \mathrm{C}$.

Feed was provided twice daily at 08:00 and 17:00 $\mathrm{h}$ as a mash. Water was continuously available through a nipple drinker. During a ten days period of adjustment to the metabolism crates and diets, average daily feed intake was gradually increased until it was estimated to supply $4 \%$ of the average BW determined at the initiation of each adaptation period. Feed refusals and spillage were collected daily and weighed. The collection and sample preparation of feces and urine were conducted according to the methods described by Song et al. [15]. Feces were collected as they appeared in the metabolism crates and placed in plastic bags to be stored at $-20^{\circ} \mathrm{C}$. Urine was collected in a bucket placed under the metabolic crate. The bucket contained $10 \mathrm{~mL}$ of $6 \mathrm{~mol} / \mathrm{L} \mathrm{HCl}$ for every $1,000 \mathrm{~mL}$ of urine. Each day, the total urine volume was measured and a $10 \%$ aliquot was filtered through gauze and the urine samples were transferred into a screw-capped tube and immediately stored at $-20^{\circ} \mathrm{C}$ until needed for analysis. At the end of the collection period, feces were thawed, pooled by pig within period, homogenized, sub-sampled, dried for $72 \mathrm{~h}$ in a $65^{\circ} \mathrm{C}$ drying oven and ground through a $1-\mathrm{mm}$ screen. For analysis, all the corn samples were ground through a $1-\mathrm{mm}$ screen as well.

\section{Chemical analyses}

All chemical analysis were conducted in duplicate and repeated if the results differed by more than $5 \%$. The ingredients used in this experiment were analyzed for dry matter (DM) [16], ether extract (EE) [17], ash [16], calcium [16], and phosphorus [16]. Kjeldahl $\mathrm{N}$ was determined according to the method used by Thiex et al. [18]. The content of neutral detergent fibre (NDF) and acid detergent fibre (ADF) were determined using filter bags and fiber analyzer equipment (Fiber Analyzer, Ankom Technology, Macedon, NY) following a modification of the procedure of Van Soest et al. [19]. Starch content was determined after converting starch to glucose using an enzyme assay kit (Megazym International Ireland, Wicklow, Ireland). The GE of feces, diets and corn samples were measured using an automatic adiabatic oxygen bomb calorimeter (Parr 6300 Calorimeter, Moline, IL). The GE of urine was measured by injecting $4 \mathrm{ml}$ of the sample into 2 filter papers in a special crucible, and dried for $8 \mathrm{~h}$ in a $65^{\circ} \mathrm{C}$ drying oven to determine the energy. The 1,000-kernel weight (g/1,000 seeds) was measured in each sample of test corn by first cleaning it of all foreign materials and then counting 1,000 seeds.

\section{Calculations and statistical analysis}

The apparent total tract digestibility (ATTD) of GE was measured on the 100 feed samples and was later converted to reflect the digestibility of the individual corn sample. The small portion of the experimental diets that consisted of minerals and vitamins (3.2\%) was assumed to have a negligible contribution to the digestibility of GE.

This experiment was a completely randomized design; the data were analyzed using the mean, correlation, GLM, and one-way ANOVA procedures of SAS (SAS Inst. Inc., NC). The individual animal and corn sample were the experimental units for analyzing the data from the digestibility trial and analysis of the chemical constituents, respectively. The relationship between physical characteristic, chemical composition, DE and ME were analyzed using the CORR procedures of SAS (1991). The linear regression equations for predicting the $\mathrm{DE}$ and $\mathrm{ME}$ value of the corn from the chemical constituents were calculated with the forward stepwise regression procedure within SAS (1991). The level of significance adopted was $5 \%(P<0.05)$. The equations with the smallest RSD are presented in the results.

\section{Results}

Chemical characteristics, physical characteristics and gross energy of corn

As expected, the chemical composition and physical characteristics of corn were quite variable for some criteria (Table 1). On a dry matter basis, the concentration of CP ranged from 7.78 to $11.03 \%$ with a mean of $9.69 \%$. Ash concentration ranged from 0.99 to $1.79 \%$ with a mean of $1.36 \%$. The variation was particularly high within the main fiber fractions as NDF concentration in 
corn ranged from 9.56 to $17.36 \%$ (mean 11.13\%) of DM, while values for ADF in corn ranged from 1.86 to $2.95 \%$ (mean 2.29\%) of DM. Concentrations of EE and starch varied greatly as well, ranging from 2.04 to $4.81 \%$ and from 53.46 to $79.80 \%$ and averaging 3.65 and $72.77 \%$, respectively. In contrast, GE content of the corn samples varied slightly. The bulk weight of corn ranged from 573.62 to $752.39 \mathrm{~g} / \mathrm{L}$ (mean $698.68 \mathrm{~g} / \mathrm{L}$ ). The 1,000 kernel weight varied greatly as well, ranging from 220.20 to $411.10 \mathrm{~g}$ (mean $325.48 \mathrm{~g}$ ).

\section{Energy concentration and energy digestibility of corn}

Energy concentration and the ATTD of GE of the corn are shown in Table 3. In the 100 corn samples, DE content ranged from 3,931 to $4,180 \mathrm{kcal} / \mathrm{kg}$ with a mean DE content of $4,053 \mathrm{kcal} / \mathrm{kg}$, resulting in a $6 \%$ range in DE. The ME content ranged from 3,798 to $4,092 \mathrm{kcal} / \mathrm{kg}$ with a mean ME content of 3,923 kcal/kg, and the overall variation in ME was $294 \mathrm{kcal}$. The ratio of ME to DE calculated from 100 measured samples ranged from 95.41 to $98.13 \%$ with a mean value of $96.78 \%$. The ATTD of GE ranged from 83.43 to $92.25 \%$ with a mean of $90.49 \%$.

\section{Effect of growing region on chemical characteristics, physical characteristics and energy values}

With exception to ash content and bulk weight (Table 4), the chemical characteristics, physical characteristics and energy values of corn were influenced significantly by growing region $(P<0.01)$. Among five provinces, Henan had the highest starch, NDF and energy content (GE, DE and $\mathrm{ME}$ ) and corn had a larger 1,000-kernel weight when grown in the Liaoning (354.59 g) and Jilin (363.60 g) provinces compared with corn grown in the Henan (299.70 g) and Shandong (307.38 g) provinces. The DE content of corn grown in Liaoning $(4,032.69 \mathrm{kcal} / \mathrm{kg})$ and Jilin $(4,035.85 \mathrm{kcal} / \mathrm{kg})$ provinces were similar; however, the DE content of corn grown in Shandong $(3,996.61 \mathrm{kcal} / \mathrm{kg})$ province was lowest. Overall, growing region significantly influenced the DE content of corn $(P<0.01)$. Corns grown in the spring growing areas (Liaoning and Jilin provinces) had a significantly higher 1,000-kernel weight compared with corn grown in the summer growing areas (Henan and Shandong provinces).

Table 3 Energy concentration and ATTD of GE of the 100 corn samples

\begin{tabular}{lcccrr}
\hline Item & Mean & Minimum & Maximum & SD & CV \\
\hline $\mathrm{DE}, \mathrm{kcal} / \mathrm{kg}$ of DM & 4,053 & 3,931 & 4,180 & 60.39 & 1.49 \\
ME, kcal/kg of DM & 3,923 & 3,798 & 4,092 & 55.42 & 1.41 \\
ME/DE & 96.78 & 95.41 & 98.13 & 1.01 & 1.04 \\
ATTD of GE, \% & 91.15 & 83.27 & 93.07 & 0.97 & 1.06 \\
\hline
\end{tabular}

\section{Correlation coefficients between physical and chemical} characteristics and energy values

In the 100 corn samples, fibrous compounds had a negative correlation with $\mathrm{DE}$ and $\mathrm{ME}$ content, while the correlation of $\mathrm{EE}, \mathrm{GE}$ and starch with $\mathrm{DE}$ content was positive (Table 4). The content of EE had the highest correlation of any characteristic with DE content $(\mathrm{r}=0.44 ; P<0.01)$, followed by total starch $(\mathrm{r}=0.38 ; P<0.01)$, NDF $(\mathrm{r}=-0.32$; $P<0.01)$ and ash $(\mathrm{r}=-0.29 ; P<0.05)$. Correlation analyses showed that ME content of corn was positively correlated to the $\mathrm{DE}(\mathrm{r}=0.95 ; P<0.01)$ and $\mathrm{EE}$ content $(\mathrm{r}=0.29$; $P<0.01)$, while ash $(\mathrm{r}=-0.28, \quad P<0.01)$ and NDF $(\mathrm{r}=-0.27, P<0.01)$ had a negative correlation with $\mathrm{ME}$ content. The correlation of bulk weight and 1,000-kernel weight with energy content was not significant (Table 5).

\section{Prediction equations for digestible energy and metabolizable energy}

Some equations based on simple and multiple linear regression analysis were then conducted to develop prediction equations for DE content of corns based on the results of stepwise regression analysis (Table 6). According to the high correlation between $\mathrm{DE}$ and $\mathrm{EE}$ content (Table 5), the best single predictor was always the EE estimate. Prediction slightly improved when the starch content was included (Equation 2 in Table 6). Addition of NDF and GE content to the equation improved the precision of the prediction (Equations 3 and 4 in Table 6). Among the different predictors, the predictions with the lowest RSD were obtained when EE, starch, NDF, and GE were considered (Equation 4 in Table 6). The residual standard deviation (RSD) was then equivalent to $48 \mathrm{kcal}$ of DM.

Equations for estimating $\mathrm{ME}$ content from chemical characteristics were calculated similarly. The results showed that the ME content of corn could be predicted with a reasonable degree of accuracy by measuring the DE (Equation 9 in Table 7). As with DE, the addition of NDF and ash content to the equation improved the precision of the prediction (Equations 10 and 11 in Table 7). The content of ME can also be accurately predicted from CP, EE, NDF and ash contents without DE content (RSD, $35 \mathrm{kcal} / \mathrm{kg}$ of DM) (Equation 8 in Table 7).

\section{Comparison of DE content in corn determined by using the in vivo method and prediction model}

To test the suitability of these models (Table 6) to predict the DE content of a normal corn sample, the DE content of 40 samples of corn was measured by both the in vivo method and prediction models (Equation 4 in Table 6). Our results showed that the maximum absolute difference between $\mathrm{DE}$ determined by the in vivo method and the prediction model was $104.61 \mathrm{kcal} / \mathrm{kg}$, while the minimum absolute difference was $0.15 \mathrm{kcal} / \mathrm{kg}$ 
Table 4 Effect of growing region on chemical characteristics, physical characteristics and energy values of the 100 corn samples from five provinces

\begin{tabular}{|c|c|c|c|c|c|c|c|}
\hline Item & Liaoning & Jilin & Hebei & Henan & Shandong & SEM & $P$-value \\
\hline \multicolumn{8}{|c|}{ Chemical composition, \% of DM } \\
\hline Dry matter & $87.57^{b}$ & $88.15^{a}$ & $86.82^{c}$ & $86.49^{d}$ & $88.20^{a}$ & 0.47 & 0.01 \\
\hline Crude protein & $9.87^{\mathrm{a}}$ & $9.78^{\mathrm{a}}$ & $9.38^{b}$ & $9.61^{a b}$ & $9.82^{\mathrm{a}}$ & 0.47 & 0.01 \\
\hline Ether extract & $3.54^{\mathrm{b}}$ & $3.38^{\mathrm{b}}$ & $4.05^{\mathrm{a}}$ & $3.71^{\mathrm{b}}$ & $3.56^{\mathrm{b}}$ & 0.05 & 0.01 \\
\hline ADF & $2.28^{b}$ & $2.22^{\mathrm{b}}$ & $2.46^{\mathrm{a}}$ & $2.29^{b}$ & $2.25^{\mathrm{b}}$ & 0.22 & 0.01 \\
\hline NDF & $10.95^{\mathrm{bc}}$ & $10.73^{c}$ & $10.76^{c}$ & $11.76^{\mathrm{a}}$ & $11.46^{\mathrm{ab}}$ & 0.86 & 0.01 \\
\hline Ash & 1.61 & 1.62 & 1.58 & 1.60 & 1.63 & 0.10 & 0.55 \\
\hline Starch & $70.58^{c}$ & $73.20^{\mathrm{b}}$ & $72.97^{\mathrm{b}}$ & $75.32^{\mathrm{a}}$ & $71.79^{\mathrm{bc}}$ & 2.97 & 0.01 \\
\hline \multicolumn{8}{|l|}{ Physical characteristic } \\
\hline Bulk weight, g/L & 693.29 & 689.94 & 699.21 & 707.94 & 703.04 & 25.60 & 0.18 \\
\hline 1,000 kernel weight, $\mathrm{g}$ & $354.69^{a}$ & $363.60^{a}$ & $302.19^{b}$ & $299.70^{\mathrm{b}}$ & $307.38^{b}$ & 30.92 & 0.01 \\
\hline \multicolumn{8}{|c|}{ Energy concentration, $\mathrm{kcal} / \mathrm{kg}$ of DM } \\
\hline Gross energy & $4448.16^{\mathrm{b}}$ & $4436.57^{b}$ & $4435.73^{b}$ & $4476.82^{a}$ & $4436.69^{b}$ & 18.23 & 0.01 \\
\hline Digestible energy & $4032.85^{b}$ & $4035.85^{b}$ & $4093.45^{\mathrm{a}}$ & $4106.23^{\mathrm{a}}$ & $3996.61^{c}$ & 45.20 & 0.01 \\
\hline Metabolisable energy & $3906.83^{b}$ & $3903.14^{b}$ & $3970.06^{a}$ & $3968.63^{\mathrm{a}}$ & $3868.94^{c}$ & 40.61 & 0.01 \\
\hline
\end{tabular}

a-d Means followed by the same letter within each row are not significantly different from each other $(P>0.05)$.

(Table 8). The mean of observed group and prediction group were 4,035.05 and 4,021.73 $\mathrm{kcal} / \mathrm{kg}$, and the difference was only $13.32 \mathrm{kcal} / \mathrm{kg}$. Therefore, the prediction models established from 60 corn samples as described in this article can be used to predict the DE content of corn for pigs with acceptable accuracy.

\section{Discussion}

Chemical characteristics, physical characteristics and energy variation in corn

The chemical composition and concomitant nutritional value of corn is variable and dependent on variety, growing environment, drying temperature, starch structure and the presence of various anti-nutritive factors [8,20-27]. Comparing the present study with the National Research Council [28], mean GE concentration was identical, mean $\mathrm{CP}$ and starch concentrations were higher than the NRC (2012) values, mean EE and ADF concentrations were lower than the NRC (2012) values. Content of GE did not vary much among the 100 samples. The CV for CP, NDF, starch, and GE were within $10 \%$, but wide variations in the content of EE (CV: 14.79\%), ash (CV: 10.07\%), Ca (CV: 26.67\%), P (CV: 11.20\%) and ADF (CV: 10.04\%) were observed (Table 1). For the physical trait, the wide variation in 1,000-kernel weight also was observed (CV: 12.64\%).

Table 5 Correlation coefficients between chemical characteristics, physical characteristics and energy values of the 100 corn samples

\begin{tabular}{|c|c|c|c|c|c|c|c|c|c|c|c|}
\hline Item & $\mathrm{DE}$ & ME & $\begin{array}{l}\text { Crude } \\
\text { protein }\end{array}$ & $\begin{array}{l}\text { Ether } \\
\text { extract }\end{array}$ & ADF & NDF & Ash & $\begin{array}{l}\text { Gross } \\
\text { energy }\end{array}$ & Starch & $\begin{array}{l}\text { Bulk } \\
\text { weight }\end{array}$ & $\begin{array}{l}1,000 \text { kernel } \\
\text { weight }\end{array}$ \\
\hline$\overline{D E}$ & 1.00 & & & & & & & & & & \\
\hline ME & $0.95^{* *}$ & 1.00 & & & & & & & & & \\
\hline Crude protein & -0.15 & -0.06 & 1.00 & & & & & & & & \\
\hline Ether extract & $0.44^{* *}$ & $0.29^{* *}$ & -0.28 & 1.00 & & & & & & & \\
\hline ADF & -0.05 & -0.06 & -0.05 & 0.33 & 1.00 & & & & & & \\
\hline NDF & $-0.32^{* *}$ & $-0.27^{* *}$ & 0.14 & -0.02 & 0.68 & 1.00 & & & & & \\
\hline Ash & $-0.29^{*}$ & $-0.28^{* *}$ & 0.22 & -0.27 & -0.11 & 0.17 & 1.00 & & & & \\
\hline Gross energy & $0.25^{* *}$ & 0.23 & -0.06 & 0.14 & -0.28 & 0.19 & 0.07 & 1.00 & & & \\
\hline Starch & $0.38^{* *}$ & $0.32^{*}$ & -0.03 & 0.03 & 0.13 & 0.11 & -0.12 & 0.06 & 1.00 & & \\
\hline Bulk weight & 0.05 & 0.03 & 0.03 & 0.15 & -0.16 & 0.13 & 0.22 & 0.05 & -0.13 & 1.00 & \\
\hline $\begin{array}{l}1,000 \text { kernel } \\
\text { weight }\end{array}$ & 0.11 & 0.06 & 0.25 & 0.02 & -0.06 & -0.13 & 0.08 & 0.14 & -0.11 & 0.42 & 1.00 \\
\hline
\end{tabular}

$*, * *, P<0.05, P<0.01$, respectively. 
Table 6 Most effective prediction equations of digestible energy (kcal/kg; dry matter) based on chemical variables (\% or $\mathrm{kcal} / \mathbf{k g}$; dry matter) of the corn samples

\begin{tabular}{|c|c|c|c|c|}
\hline No. & Equation & $R^{2}$ & RSD & $P$-value \\
\hline 1 & $\mathrm{DE}=3889.81+(46.21 \times$ Ether extract $)$ & 0.20 & 59 & $<0.01$ \\
\hline 2 & $\mathrm{DE}=3335.46+(44.91 \times$ Ether extract $)+(7.59 \times$ Starch $)$ & 0.33 & 58 & $<0.01$ \\
\hline 3 & $D E=3507.46+(44.01 \times$ Ether extract $)-(20.09 \times N D F)+(8.38 \times$ Starch $)$ & 0.45 & 56 & $<0.01$ \\
\hline 4 & $\mathrm{DE}=1062.68+(49.72 \times$ Ether extract $)-(24.89 \times \mathrm{NDF})+(0.54 \times$ Gross energy $)+(9.11 \times$ Starch $)$ & 0.62 & 48 & $<0.01$ \\
\hline
\end{tabular}

Variety and growing environment are major sources of variation for the chemical composition of cereal grains [29]. Table 4 also indicated that growing regions influenced significantly the chemical characteristics, physical characteristics and energy values of corn. A previous study demonstrated that chemical composition, especially the NSP composition and structure, was significantly different due to variety and growing location and was negatively correlated with the DE content [30]. One reason for not observing a huge degree of variation in some criteria may be that no extreme samples were collected, such as high-oil corn, high-lysine corn, or NutriDense corn. The other reason is that the quality standards for corn were similar for all the feed companies who collected the samples for this study.

Corn samples were collected for use in this study to increase the likelihood of observing a degree of variation in DE and ME content of the 100 corn samples. Yellow Dent corn in the NRC [28] has a DE value of 3,921 kcal/ $\mathrm{kg}$ of DM and a ME value of $3,857 \mathrm{kcal} / \mathrm{kg}$ of DM, respectively. The average DE for corn determined in the present study was $4,053 \mathrm{kcal} / \mathrm{kg}$ of $\mathrm{DM}$, and ME averaged $3,923 \mathrm{kcal} / \mathrm{kg}$ of $\mathrm{DM}$, respectively. The difference between the current study and previous results could be attributable to differences in particle size of corn. The mean particle size of the corn reported herein was 441 $\mu \mathrm{m}$, well below the 600 to $700 \mu \mathrm{m}$ level recommended for corn fed to growing swine $[31,32]$. Data reported by Owsley et al. [33], and Healy et al. [32] suggest that the $\mathrm{DE}$ of diet increases when particle size is reduced. The screen was a new one for this study, and Chinese producers prefer the small feed particles.
The amount of energy lost in urine represented from 2 to $5 \%$ of dietary DE content (mean: $3.0 \%$ ). The mean ME:DE ratio therefore averaged 97\%. The ME:DE ratio obtained in the current study corresponds with the data published by NRC [28], which reported Yellow Dent corn had an ME:DE ratio of 98\%. Based upon the NRC [28] reported value, Noblet and Perez [13] proposed an equation $(\mathrm{ME} / \mathrm{DE}=100.3-0.21 \times \mathrm{CP})$ to be applied to feed ingredients. Under practical conditions, the dietary $\mathrm{CP}$ content is less variable, so ME:DE has been considered almost as a constant of approximately 96.78\% [34]. The mean of the ATTD of GE determined for these corn samples was $91.15 \%$, somewhat higher than standard values, which are typically $87.74 \%$ (Yellow Dent Corn) [28]. One possible explanation for the higher ATTD of GE could be the smaller than expected particle size of the ground corn.

\section{Factors influencing energy variation}

Corn is typically sold as a commodity and is valued by bulk weight, moisture content, and absence of foreign particulates. However, in this experiment, no physical parameter measured (bulk weight and 1,000 kernel weight) was significant at $P \leq 0.15$ to predict $\mathrm{DE}$ or $\mathrm{ME}$. The results obtained in the current study agreed with the data provided by Leeson [8] and Dale [9]. Such a result indicates that most of the observed variation in $\mathrm{DE}$ or ME between samples was the result of factors other than bulk weight and 1,000 kernel weight. Compared with the data of correlation coefficients (Table 5) among DE of DM values of samples in the study, EE, NDF, ash, GE and starch were $0.44,-0.32,-0.29,0.25$ and 0.38 ,

Table 7 Most effective prediction equations of ME (kcal/kg; DM) based on chemical variables (\% or kcal/kg; DM) of the corn samples

\begin{tabular}{|c|c|c|c|c|}
\hline No. & Equation & $\mathrm{R}^{2}$ & RSD & $P$-value \\
\hline 5 & $\mathrm{ME}=4190.19-(19.56 \times \mathrm{NDF})$ & 0.22 & 44 & $<0.01$ \\
\hline 6 & $\mathrm{ME}=4664.04-(17.74 \times \mathrm{NDF})-(310.93 \times$ Ash $)$ & 0.33 & 40 & $<0.01$ \\
\hline 7 & $\mathrm{ME}=4464.24+(20.15 \times$ Ether extract $)-(17.84 \times \mathrm{NDF})-(233.72 \times$ Ash $)$ & 0.44 & 39 & $<0.01$ \\
\hline 8 & $\mathrm{ME}=4289.74+(20.02 \times$ Crude protein $)+(22.47 \times \mathrm{EE})-(18.40 \times \mathrm{NDF})-(245.20 \times$ Ash $)$ & 0.49 & 35 & $<0.01$ \\
\hline 9 & $M E=-213.69+(1.02 \times D E)$ & 0.79 & 23 & $<0.01$ \\
\hline 10 & $\mathrm{ME}=362.67+(0.95 \times \mathrm{DE})-(193.59 \times \mathrm{Ash})$ & 0.85 & 19 & $<0.01$ \\
\hline 11 & $\mathrm{ME}=671.58+(0.89 \times \mathrm{DE})-(5.57 \times \mathrm{NDF})-(191.39 \times \mathrm{Ash})$ & 0.87 & 18 & $<0.01$ \\
\hline
\end{tabular}


Table 8 Comparison of digestible energy contents in corn determined by using the in vivo method and prediction model (kcal/kg of DM)

\begin{tabular}{|c|c|c|c|}
\hline Test & Observed & Predicted & Difference \\
\hline 1 & $4,084.05$ & $3,996.40$ & 87.64 \\
\hline 2 & $4,108.22$ & $4,040.57$ & 67.65 \\
\hline 3 & $4,140.16$ & $4,101.24$ & 38.92 \\
\hline 4 & $4,023.51$ & $4,019.85$ & 3.66 \\
\hline 5 & $4,113.16$ & $4,047.87$ & 65.29 \\
\hline 6 & $3,950.07$ & $4,050.91$ & -100.84 \\
\hline 7 & $4,058.73$ & $4,085.59$ & -26.85 \\
\hline 8 & $4,054.97$ & $4,062.27$ & -7.30 \\
\hline 9 & $4,046.38$ & $4,007.67$ & 38.71 \\
\hline 10 & $3,997.07$ & $3,989.82$ & 7.25 \\
\hline 11 & $4,044.88$ & $3,969.98$ & 74.89 \\
\hline 12 & $4,062.20$ & $4,042.23$ & 19.97 \\
\hline 13 & $4,062.67$ & $3,994.71$ & 67.95 \\
\hline 14 & $4,009.57$ & $3,974.33$ & 35.23 \\
\hline 15 & $3,957.41$ & $3,962.92$ & -5.51 \\
\hline 16 & $4,036.46$ & $4,036.31$ & 0.15 \\
\hline 17 & $3,983.54$ & $3,970.58$ & 12.96 \\
\hline 18 & $4,011.42$ & $3,993.93$ & 17.49 \\
\hline 19 & $3,932.03$ & $3,951.91$ & -19.88 \\
\hline 20 & $3,980.49$ & $4,035.48$ & -54.99 \\
\hline 21 & $4,065.07$ & $4,054.47$ & 61.22 \\
\hline 22 & $4,024.33$ & 4043.60 & -19.28 \\
\hline 23 & $4,025.92$ & $4,020.54$ & 5.38 \\
\hline 24 & $4,020.02$ & $4,024.04$ & -4.02 \\
\hline 25 & $4,016.88$ & $4,005.85$ & 11.03 \\
\hline 26 & $4,051.08$ & $3,996.01$ & 55.06 \\
\hline 27 & $4,058.55$ & $3,987.99$ & 70.57 \\
\hline 28 & $4,051.18$ & $4,018.28$ & 32.90 \\
\hline 29 & 4,088.96 & $4,036.06$ & 52.90 \\
\hline 30 & $4,087.01$ & $4,028.30$ & 58.71 \\
\hline 31 & $4,121.96$ & $4,017.35$ & 104.61 \\
\hline 32 & $4,084.62$ & $4,055.96$ & 28.66 \\
\hline 33 & $4,002.90$ & $4,050.52$ & -47.62 \\
\hline 34 & $3,979.24$ & $4,014.76$ & -35.52 \\
\hline 35 & $4,003.71$ & $4,022.21$ & -18.50 \\
\hline 36 & $4,066.90$ & $4,022.56$ & 44.34 \\
\hline 37 & $3,934.52$ & $4,003.62$ & -69.10 \\
\hline 38 & $4,041.55$ & $4,038.95$ & 2.59 \\
\hline 39 & $4,029.50$ & $4,062.03$ & -32.54 \\
\hline 40 & $3,991.01$ & $4,031.85$ & -40.84 \\
\hline $\mathrm{SD}^{*}$ & 49.74 & 32.93 & \\
\hline RSD** & & & 46.75 \\
\hline$P$-value & & & 0.16 \\
\hline
\end{tabular}

${ }^{*} \mathrm{SD}$, Standard deviation; ${ }^{*} \mathrm{RSD}$, residual standard deviation. respectively. Correlation coefficients and prediction equations with chemical composition clearly indicate that $\mathrm{EE}$, starch and fibrous components predominantly determined the energy values. This observation is consistent with findings for barley by Fairbairn et al. [3], in which a prediction equation with an $\mathrm{r}^{2}$ of 0.89 for DE was reported if the similar variables were used.

Ether extract and starch were important prediction estimators of DE or ME in corn. The reasons may attribute that starch and dietary fat are important ingredients in diets because of its high energy value. Interestingly, the narrow range of GE levels in the 100 corn samples using herein $(4,357$ to $4,537 \mathrm{kcal} / \mathrm{kg})$ did not seem to reduce the effectiveness of GE as an accurate estimator of $\mathrm{DE}$ or ME in corn. The reasons for this are unclear but the first estimate, based on a large set of experimental data, seems preferable. However, the coefficient of GE was positive with energy values in the study, and similar results were found in wheat (unpublished data) in our lab. Barley, wheat and sorghum showed the same result in Batterham's study [35].

In agreement with most literature data [13,36,37], the presence of fiber in the diet of pigs reduces the ATTD of energy and nutrients. The content of NDF was another significant factor affecting the $\mathrm{DE}$ and $\mathrm{ME}$ variation in the present experiment. The prediction was improved when the different Van Soest fractions were included (Equations 3 in Table 6). This significant correlation between NDF and DE in other cereal grains has been observed by Perez et al. [38] and Fairbairn et al., [3]. Other researchers have found that the NDF content of corn was correlated with growing performance of pigs [6]. The reason may be that cellulose and lignin act as a diluent, thus lowering the energy content by displacing more digestible fractions such as starch. However, the dilution effect does not fully explain the changes in energy content. It may be that the presence of fiber can reduce the digestion of dietary nutrients. The results of the present study clearly show that ME content of corn can be accurately predicted from the DE content, because the correlation coefficient between DE and ME is approximately 0.95 .

After testing the suitability of these models (Table 6) to predict the DE content of corn samples, our results showed that the difference between vivo method the prediction model was not significant $(P>0.16$ in Table 8$)$. This suggested that the accuracy of prediction models for DE was close to that obtained in vivo. In conclusion, the results of this study demonstrate that it is possible to estimate the DE and ME of corn from chemical variables. The best predictors for energy values were EE, starch, GE and NDF contents. Equation 4 (Table 6) and Equation 11 (Table 7) represent the best combination of accuracy and practicality when estimating DE and ME levels in corn. 


\section{Abbreviations}

DE: Digestible energy; ME: Metabolizable energy; CP: Crude protein; NDF: Neutral detergent fibre; ADF: Acid detergent fibre; ATTD: Apparent total tract digestibility; DDGS: Distillers dried grains with soluble; EE: Ether extract; GE: Gross energy; DM: Dry matter; RSD: Residual standard deviation.

\section{Competing interests}

The authors declare that they have no competing interests.

\section{Authors' contributions}

QFL carried out the experiment trial, performed the statistics and drafted the manuscript. JJZ and XSP participated in design of the study. DWL participated animal trial. DFL and CHL conceived the study, and participated in its design and coordination. All authors read and approved the final manuscript.

\section{Acknowledgements}

This research was financially supported by the National Key Technology R \& D Program in the 11th Five Year Plan of China (2006BAD12B01) and Special Public Sector Fund in Agriculture (200903006). Thanks to Chuanxin Shi, Zhongchao Li and Zhaoyu Liu for their practical support.

Received: 2 November 2013 Accepted: 9 February 2014 Published: 13 February 2014

\section{References}

1. Dozier WA, Gehring CK, Corzo A, Olanrewaju HA: Apparent metabolizable energy needs of male and female broilers from 36 to 47 days of age. Poult Sci 2011, 90:804-814.

2. Cowieson AJ: Factors that affect the nutritional value of maize for broilers. Anim Feed Sci Technol 2005, 119:293-305.

3. Fairbairn SL, Patience JF, Classen HL, Zijlstra RT: The energy content of barley fed to growing pigs: characterizing the nature of its variability and developing prediction equations for its estimation. J Anim Sci 1999, 77:1502-1512

4. Spencer JD, Allee GL, Sauber TE: Growing-finishing performance and carcass characteristics of pigs fed normal and genetically modified low-phytate corn. J Anim Sci 2000, 78:1529-1536.

5. Lampe JF, Baas TJ, Mabry JW: Comparison of grain sources for swine diets and their effect on meat and fat quality traits. J Anim Sci 2006, 84:1022-1029.

6. Moore SM, Stalder KJ, Beitz DC, Stahl CH, Fithian WA, Bregendahl K: The correlation of chemical and physical corn kernel traits with growth performance and carcass characteristics in pigs. J Anim Sci 2008, 86:592-601.

7. de Coca-Sinova A, Valencia DG, Jiménez-Moreno E, Lázaro R, Mateos GG: Apparent ileal digestibility of energy, nitrogen, and amino acids of soybean meals of different origin in broilers. Poult Sci 2008, 87:2613-2623.

8. Leeson S, Yersin A, Volker L: Nutritive values of 1992 corn crop. J Appl Poult Res 1993, 2:208-213.

9. Dale N, Jackson D: True metabolizable energy of corn fractions. J Appl Poult Res 1994, 3:179-183.

10. Pedersen $\mathrm{C}$, Boersma MG, Stein $\mathrm{HH}$ : Digestibility of energy and phosphorus in 10 samples of distillers dried grains with solubles fed to growing pigs. J Anim Sci 2007, 85:1168-1176.

11. Cozannet P, Primot C, Gady C, Metayer JP, Lessire M, Skiba F, Noblet J: Energy value of wheat distillers grains with solubles for growing pigs and adult sows. J Anim Sci 2010, 88:2382-2392.

12. Zijlstra RT, De Lange CFM, Patience JF: Nutritional value of wheat for growing pigs: chemical composition and digestible energy content. Can J Anim Sci 1999, 79:187-194.

13. Noblet J, Perez JM: Prediction of digestibility of nutrients and energy values of pig diets from chemical analysis. J Anim Sci 1993, 71:3389-3398.

14. NRC: Nutrient requirements of swine 10th rev. ed. Washington DC, USA: National Academy Press; 1998.

15. Song GL, Li DF, Piao XS, Chi F, Yang WJ: Apparent ileal digestibility of amino acids and the digestible and metabolizable energy content of high-oil corn varieties and its effects on growth performance of pigs. Arch Anim Nutr 2003, 57:297-306.

16. AOAC: Official methods of analysis. 17th ed. Arlington, VA, USA: Association of Official Analytical Chemists; 2000 .

17. Thiex NJ, Anderson S, Gildemeister B: Crude fat, diethyl ester extraction, in feed, cereal grain, and forage (Randall/Soxtec/submersion method): collaborative study. J AOAC Int 2003, 86:888-898.
18. Thiex NJ, Manson H, Anderson S, Persson JA: Determination of crude protein in animal feed, forage, grain, and oilseeds by using block digestion with copper catalyst and steam distillation into boric acid: collaborative study. J AOAC Int 2002, 85:309-317.

19. Van Soest PJ, Robertson JB, Lewis BA: Methods for dietary fiber and non-starch polysaccharides in relation to animal nutrition. J Dairy Sci 1991, 74:3568-3597.

20. Leigh K: The unpredictable nature of maize. Pigs; 1994:37-39.

21. Brown I: Complex carbohydrates and resistant starch. Nutr Rev 1996, 54:115-119.

22. Collins NE, Moran ET, Stilborn HL: Maize hybrid and bird maturity affect apparent metabolizable energy values. Poult Sci 1998, 11:42.

23. Cromwell GL, Calvert CC, Cline TR, Crenshaw JD, Crenshaw TD, Easter RA Ewan RC, Hamilton CR, Hill GM, Lewis AJ, Mahan DC, Miller ER, Nelssen JL, Pettigrew JE, Tribble LF, Veum TL, Yen JT: Variability among sources and laboratories in nutrient analyses of maize and soybean meal. J Anim Sci 1999, 77:262-3273.

24. Collins NE, Moran JR: Influence of yellow dent maize hybrids having different kernel characteristics yet similar nutrient composition on broiler production. J Appl Anim Res 2001, 10:228-235.

25. Bohlke RA, Thaler RC, Stein HH: Calcium, phosphorus, and amino acid digestibility in low-phytate corn, normal corn, and soybean meal by growing pigs. J Anim Sci 2005, 83:2396-2403.

26. Bird AR, Vuaran M, Brown I, Topping DL: Two high-amylose maize starches with different amounts of resistant starch vary in their effects on fermentation, tissue and digesta mass accretion, and bacterial populations in the large bowel of pigs. Br J Nutr 2007, 97:134-144.

27. Oliveira GCD, Moreira I, Furlan AC, Piano LM, Toledo JB, Peñuela Sierra LM: Corn types with different nutritional profiles, extruded or not, on piglets (6 to $15 \mathrm{~kg}$ ) feeding. Revista rasileira de Zootecnia 2011, 40:2462-2470.

28. NRC: Nutrient requirements of swine 11th rev. ed. Washington DC, USA: National Academy Press; 2012.

29. Kim JC, Simmins PH, Mullan BP, Pluske JR: The digestible energy value of wheats for pigs, with special reference to the post-weaned animal. Anim Feed Sci Technol 2005, 122:257-287.

30. Kim JC, Mullan BP, Simmins PH, Pluske JR: Effect of variety, growing region and growing season on digestible energy content of wheats grown in Western Australia for weaner pigs. Anim Sci 2004, 78:53-60.

31. Wondra KJ, Hancock JD, Behnke KC, Stark CR: Effects of mill type and particle size uniformity on growth performance, nutrient digestibility, and stomach morphology in finishing pigs. J Anim Sci 1995, 73:2564-2573.

32. Healy BJ, Hancock JD, Kennedy GA, Bramel-Cox PJ, Behnke KC, Hines RH: Optimum particle size of corn and hard and soft sorghum for nursery pigs. J Anim Sci 1994, 72:2227-2236.

33. Owsley WF, Knabe DA, Tanksley TD: Effect of sorghum particle size on digestibility of nutrients at the terminal ileum and over the total digestive tract of growing-finishing pigs. J Anim Sci 1981, 52:557-566.

34. Morgan CA, Whittemore CT, Phillips P, Crooks P: The prediction of the energy value of compounded pig foods from chemical analysis. Anim Feed Sci Technol 1987, 17:81-107.

35. Batterham ES, Lewis CE, Lowe RF, McMillan CJ: Digestible energy content of cereals and wheat by-products for growing-pigs. Anim Prod 1980 31:259-271.

36. Dierick NA, Vervaeke IJ, Decuypere JA, Henderickx HK: Influence de la nature et du niveau des fibres brutes sur la digestibilite ileale et fecale apparente de la matiere seche, des proteines et des acides amines et sur la retention azotee chez les porcs. Rev Agric 1983, 6:1691-1711.

37. Stanogias G, Pearce GR: The digestion of fibre by pigs, I. The effects of amount and type of fibre on apparent digestibility, nitrogen balance and rate of passage. Br J Nutr 1985, 53:513-530.

38. Perez JM, Ramoelintsalama B, Bourdon D: Energy evaluation of barley for pigs. Prediction from analyses of fiber content. J Rech Porcine Fr 1980, $12: 273-284$

doi:10.1186/2049-1891-5-11

Cite this article as: Li et al.: Predicting corn digestible and metabolizable energy content from its chemical composition in growing pigs. Journal of Animal Science and Biotechnology 2014 5:11. 